\title{
Knowledge, Attitude and Preventive Practices towards Sexually Transmitted Infection among Preparatory School Students of Arsi Negelle Town
}

\section{Nega Degefa Megersa*, Sindew Mohamud Ahmed, Befikadu Tariku Gutema, Girum Sebsebie Teshome, Zeleke Aschalew Melketsedik and Eshetu Zerihun Tariku}

Arbaminch University, Arbaminch, Ethiopia

\begin{abstract}
Background: Sexually transmitted infections (STIs) are a major global cause of acute illness, infertility, long-term disability and death with serious medical and psychological consequences of millions of men, women and infants. Due to their high prevalence, particularly in developing settings, STIs result in substantial productivity losses for individuals and communities, particularly where the majority of the population is less than 40 years of age.
\end{abstract}

Objective: To assess knowledge, attitude and preventive practices of Arsi Negelle preparatory students towards STIs.

Methodology: Institutional based cross-sectional study design and quantitative method of data collection were employed. A Proportionate Stratified random sampling technique was used and finally, a total of 303 respondents were selected by systematic random sampling method. A standardized self-administered questionnaire was used to collect information from respondents

Results: Half of the respondents (50.8\%) had good knowledge about STIs and $54.5 \%$ of respondents were identified to have positive attitude towards STIs and $38.6 \%$ of respondents had good preventive practice despite the fact that the rest $61.4 \%$ had poor preventive practice towards STIs.

Conclusion: Most of respondents had heard about STIs in one or another way however nearly half of respondent's have good knowledge regarding STIs. This study had called for continued and strengthened health education.

Keywords: Sexually transmitted infection; Knowledge; Attitude; Practice

\section{Introduction}

The term sexually transmitted infection (STI) is used to denote a variety of clinical conditions that are caused by pathogens which can be acquired and transmitted through sexual activity [1]. STIs are transmitted predominantly through unprotected sex and can also be transmitted during childbirth or breastfeeding, as well as sharing needle [2]. STIs are caused by more than 30 different kinds of pathogens including bacteria, virus, protozoa, and fungus. There are both curable and non-curable but preventable STIs $[3,4]$.

World Health Organization estimated new cases for the four common STIs to be 498.9 million, in 2008, which holds 105.7 million cases of C. trachomatis, 106.1 million cases of $N$. gonorrhea, 10.6 million cases of syphilis and 276.4 million cases of T. vaginalis in people aged 15-49 annually. In addition, 536 million people are estimated to be living with incurable herpes simplex virus type 2 (HSV-2) infection approximately 291 million women have a human papillomavirus (HPV) infection at any given point in time [4-7]. Globally, an estimated 35.3 (32.2-38.8) million people were living with HIV in 2012. There was an average of 2.3 (1.9-2.7) million new HIV infections globally [8].

Worldwide, up to 4000 newborn babies become blind every year because of eye infections attributable to untreated maternal gonococcus and chlamydial infections. In pregnancy, untreated early syphilis resulted in a stillbirth rate of $25 \%$ and be responsible for $14 \%$ of neonatal deaths and an overall perinatal mortality of about $40 \%$ [9].

In most African countries STIs remain the major public problem on account of their frequency, associated morbidity and mortality and their economic cost. Prevalence of syphilis in pregnant women in Africa ranges from $4 \%-15 \%[4,10,11]$. The incidence of selected curable
STIs for WHO African regions estimated to be 92.6 million: with 8.3 million cases of $C$. trachomatis, 21.1 million cases of $N$. gonorrhea, 3.4 million cases of syphilis and 59.7 million cases of T. vaginalis [6].

In Ethiopia currently, there is no systematic collection of surveillance data on STIs, despite the routine syphilis tests for a pregnant mom with the current national prevalence of 1.8\%. [4,12]. However, the 2011 Ethiopian Demographic Health Survey (EDHS) presented a self-reported prevalence of STIs among women and men aged $15-49$ years, $4.6 \%$ and $6.8 \%$, respectively reported having STIs in the past 12 months [13].

Knowledge, attitude and preventive practice of students on STI especially on HIV has been extensively studied; however most of the literature doesn't address knowledge, attitude and preventive practice of STIs other than HIV. So, this study assessed knowledge, attitude, and preventive practices of Arsi Negelle preparatory school students towards the common STIs including HIV.

This study provided a baseline data for the town health office on gaps between dissemination of health information and students current

*Corresponding author: Nega Degefa Megersa, MSc, Arbaminch University, Arbaminch, Ethiopia; Tel: +251921219662; 0461161218; Fax: +2510468810279; E-mail:negshd05@gmail.com

Received November 27, 2017; Accepted December 20, 2017; Published December 27, 2017

Citation: Megersa ND, Ahmed SM, Gutema BT, Teshome GS, Melketsedik ZA et al. (2017) Knowledge, Attitude and Preventive Practices towards Sexually Transmitted Infection among Preparatory School Students of Arsi Negelle Town. J AIDS Clin Res 8: 748. doi: 10.4172/2155-6113.1000748

Copyright: (C) 2017 Megersa ND, et al. This is an open-access article distributed under the terms of the Creative Commons Attribution License, which permits unrestricted use, distribution, and reproduction in any medium, provided the original author and source are credited. 
Citation: Megersa ND, Ahmed SM, Gutema BT, Teshome GS, Melketsedik ZA, et al. (2017) Knowledge, Attitude and Preventive Practices towards Sexually Transmitted Infection among Preparatory School Students of Arsi Negelle Town. J AIDS Clin Res 8: 748. doi: 10.4172/21556113.1000748

Page 2 of 6

level of awareness, the lived perception and preventive practice towards STIs.

\section{Materials and Methods}

\section{Study area}

This cross sectional quantitative study was carried out from March 15-April 1 at Arsi Negelle town which is located in south eastern part of Ethiopia and in Mirab Arsi zone of Oromia region on the paved high way north of Shashemene. The town is $228 \mathrm{~km}$ away from Addis Ababa. According to the 2007 national census total population for this worked was 260,129 of whom 128,885 were men and 131,244 were women [14].

\section{Sample size and sampling procedure}

Sample size was determined by using formula for single population proportion by considering assumption like; $95 \%$ confidence level, $5 \%$ margin of error and prevalence of outcome variable that yields largest sample size (knowledge) was considered which is $39 \%$ from previous study at Gonder $(\mathrm{p}=0.39)$.

$$
\begin{aligned}
& \boldsymbol{n}=\underline{\boldsymbol{z a}}_{\underline{2}} \underline{2} p(1-p) n=(1.96)^{2} \underline{0.39(1-0.39)}=366 \\
& d^{2}(0.05)^{2}
\end{aligned}
$$

The sample size was corrected using the following formula $n f=$ no $=366 / 1+366 / 1100=2751+$ no $/ \mathrm{N}$

After considering $10 \%$ for non-response rate the final sample size will be 303.

The total calculated sample size was selected from all section by systematic random sampling method by using their registration number as reference.

\section{Data collection procedures and instrument}

A self-administered questionnaire with four parts was used for data collection. $1^{\text {st }}$ Questions regarding Sociodemographic background of students, $2^{\text {nd }}$ - Question concerning knowledge of students about STI $3^{\text {rd }}$ - Question assessing attitude of students towards STI and $4^{\text {th }}$ Question evaluating preventive practices of students. One day training was given for data collectors and supervisors. A pretest was done on 5\% of the sample.

\section{Data processing and analysis}

The data was entered by using EPI data version 3.1. Software then exported to SPSS version 20 for analysis. Descriptive statistics was used to organize and summarize back ground variables. The association between variables was measured and tested by using bivariate and multivariate logistic regression.

\section{Scoring}

Each right answer was given 1 and wrong or uncertain answer was score 0 . Total knowledge scores ranges from 0-43. Knowledge scores from 0 to 19.23 were considered as poor knowledge while knowledge scores more than 19.23 was considered as having good knowledge regarding STI

Attitude concerning STIs patients was assessed using a 9 item questionnaire where, attitude scores between $0-7.5$ were considered as unfavorable attitude, and scores 7.5-9 were considered as positive attitude.

If students answer more than the mean score out of prepared practice questions where as poor preventive practice: If students answer less than the mean score out of prepared practice questions.

\section{Ethical consideration}

This study was approved by Ethical Review Board of Addis Ababa University College of health sciences, school of allied health science. Participants were assured that their personal information and answers would remain confidential

\section{Results}

\section{Sociodemographic characteristics of respondents}

A total of 303 Kilture Preparatory School students participated in the study with a response rate of $100 \%$. The age of respondent's range from 16-24 years with mean age of $18.53 \pm 1.402$ years. $181(59.7 \%)$ of respondents were male (Table 1).

\section{Knowledge of Kilture Preparatory School students about STIs}

Concerning types of STIs 262 (86.50\%), 256 (84.5\%), 194 (64.0\%), 76 (25.1\%), 7 (2.3\%), 4 (1.3\%) had mentioned HIV, gonorrhea, syphilis, chancroid, Hepatitis B and Hepatitis C, respectively. 10 (3.3\%) of respondents had mentioned TB as one of STIs erroneously. $88.9 \%$ of respondent identified virus as a primary cause for STIs, $32.6 \%$ bacteria, $28.4 \%$ fungus, and there were also respondents who replied wrong answers like bad hygiene of women or men 73 (24.5\%), using unclean water $7(2.3 \%)$ and sex during menstruation $54(18.1 \%)$ as a cause for STIs. 302 (99.7\%) of respondents mention that STI can transmit from person to person and $274(90.4 \%)$ of them stated sexual intercourse as

\begin{tabular}{|c|c|c|c|}
\hline Variables & Category & Frequency $(\mathrm{N})$ & Percentage (\%) \\
\hline \multirow[t]{2}{*}{ Age } & $15-19$ & 243 & 80.2 \\
\hline & $20-24$ & 60 & 19.8 \\
\hline \multirow[t]{2}{*}{ Sex } & Male & 181 & 59.7 \\
\hline & Female & 122 & 40.3 \\
\hline \multirow[t]{5}{*}{ Religion } & Orthodox & 146 & 48.2 \\
\hline & Muslim & 74 & 24.4 \\
\hline & Catholic & 10 & 3.3 \\
\hline & Protestant & 62 & 20.5 \\
\hline & Other & 11 & 3.6 \\
\hline \multirow[t]{5}{*}{ Ethnicity } & Oromo & 204 & 67.3 \\
\hline & Amara & 65 & 21.5 \\
\hline & Tigre & 12 & 4 \\
\hline & Wolayita & 3 & 1 \\
\hline & Other & 19 & 6.3 \\
\hline \multirow[t]{2}{*}{ Grade of student } & 11 & 190 & 62.7 \\
\hline & 12 & 113 & 37.3 \\
\hline \multirow{4}{*}{$\begin{array}{l}\text { With whom do } \\
\text { you live? }\end{array}$} & Parents or family & 254 & 83.8 \\
\hline & Friends or friend in rent & 26 & 8.6 \\
\hline & Alone in rental home & 15 & 5.0 \\
\hline & Others & 8 & 2.6 \\
\hline \multirow{2}{*}{$\begin{array}{l}\text { Do you have boyl } \\
\text { girl friend? }\end{array}$} & Yes & 109 & 36.0 \\
\hline & No & 194 & 64.0 \\
\hline \multirow{4}{*}{$\begin{array}{l}\text { Mothers level of } \\
\text { education }\end{array}$} & No formal education & 58 & 19.1 \\
\hline & Primary & 100 & 33 \\
\hline & Secondary & 84 & 27.7 \\
\hline & College and above & 61 & 20.1 \\
\hline \multirow{4}{*}{$\begin{array}{l}\text { Fathers level of } \\
\text { education }\end{array}$} & No formal education & 34 & 11.2 \\
\hline & Primary & 93 & 30.7 \\
\hline & Secondary & 92 & 30.4 \\
\hline & College and above & 84 & $27.7 \%$ \\
\hline
\end{tabular}
a primary mode of transmission (Table 2).

Table 1: Sociodemographic characteristics of Arsi Negelle Kilture Preparatory School student's west Arsi zone, Oromia, Ethiopia 2016. 
Citation: Megersa ND, Ahmed SM, Gutema BT, Teshome GS, Melketsedik ZA, et al. (2017) Knowledge, Attitude and Preventive Practices towards Sexually Transmitted Infection among Preparatory School Students of Arsi Negelle Town. J AIDS Clin Res 8: 748. doi: 10.4172/21556113.1000748

Page 3 of 6

$259(85.8 \%)$ of respondent mentioned condom as first line prevention method and 7 (2.3\%) incorrectly said that not eating with infected

\begin{tabular}{|c|c|c|c|}
\hline Variables & Response & Frequency $(\mathrm{N})$ & Percent (\%) \\
\hline \multirow[t]{2}{*}{ Do STIs transmittable? } & Yes & 302 & 99.7 \\
\hline & No & 1 & 0.3 \\
\hline \multirow{6}{*}{$\begin{array}{l}\text { What are the modes of } \\
\text { transmission? }\end{array}$} & Unprotected sex & 274 & 90.7 \\
\hline & Blood transfusion & 142 & 47 \\
\hline & Sharing needle & 230 & 76.2 \\
\hline & Mother to child & 178 & 58.9 \\
\hline & Mosquito bite * & 25 & 8.3 \\
\hline & Sharing cloths * & 23 & 7.6 \\
\hline \multirow[t]{2}{*}{ Can we prevent STIs? } & Yes & 302 & 99.7 \\
\hline & No & 1 & 0.3 \\
\hline \multirow{5}{*}{$\begin{array}{l}\text { What are the prevention } \\
\text { methods? }\end{array}$} & Condom & 259 & 85.8 \\
\hline & Abstinence & 245 & 81.1 \\
\hline & $\begin{array}{l}\text { Not eating with } \\
\text { STIs patients * }\end{array}$ & 7 & 2.3 \\
\hline & $\begin{array}{l}\text { Not having multiple } \\
\text { sexual partner }\end{array}$ & 181 & 59.9 \\
\hline & $\begin{array}{c}\text { Not receiving } \\
\text { unscreened blood }\end{array}$ & 213 & 70.5 \\
\hline
\end{tabular}

* Wrong answers mentioned by respondents

Table 2: Modes of transmission and prevention method of STIs of Kilture Preparatory school students, Arsi Negelle town, west Arsi zone, 2016 individual can prevent the spread of the disease. Regarding the sign and symptoms of STIs 215 (72.4\%) respondents knew discharge from vagina or urethra, $169(56.9 \%)$ loss of body weight, $163(54.9 \%)$ genital ulcers or open sores, 56 (52.5\%) itching of genital area, 135 (45.5\%) failure to urinate, $122(41.1 \%), 20(6.7 \%)$ lower abdominal pain and $6(2 \%)$ of respondent replied that they don't know any sign and symptom of STIs. 154 (50.8\%) of respondents were knowledgeable about the common aspect of STIs. The mean score of respondents was $19.23 \pm 5.73$ with minimum and maximum score of 8 and 38 , respectively (Figure 1).

\section{Attitude of Kilture Preparatory School students towards STIs}

$165(54.5 \%)$ of respondents had positive attitude while the rest 138 (45.5\%) had negative attitude about STIs. 233 (76.9\%) of respondents believe that people who had STI can't be easily identified in the community, 189 (62.4\%) of respondents perceives that STIs are not dangerous as afar as they can be treated, $69(22.8 \%)$ of respondents misperceive that isolating individuals with STIs can help prevent the spread of the disease (Table 3).

\section{Preventive practices of Kilture Preparatory School students}

$117(38.6 \%)$ of respondents reported as they had history of sexual intercourse and $54(46.2 \%)$ of them perform with fixed friend, 61 (52.1\%) with causal friend and $2(1.7 \%)$ with other. From those who encounter sexual intercourse $29 \%$ had used condom while $29(9.6 \%)$ of

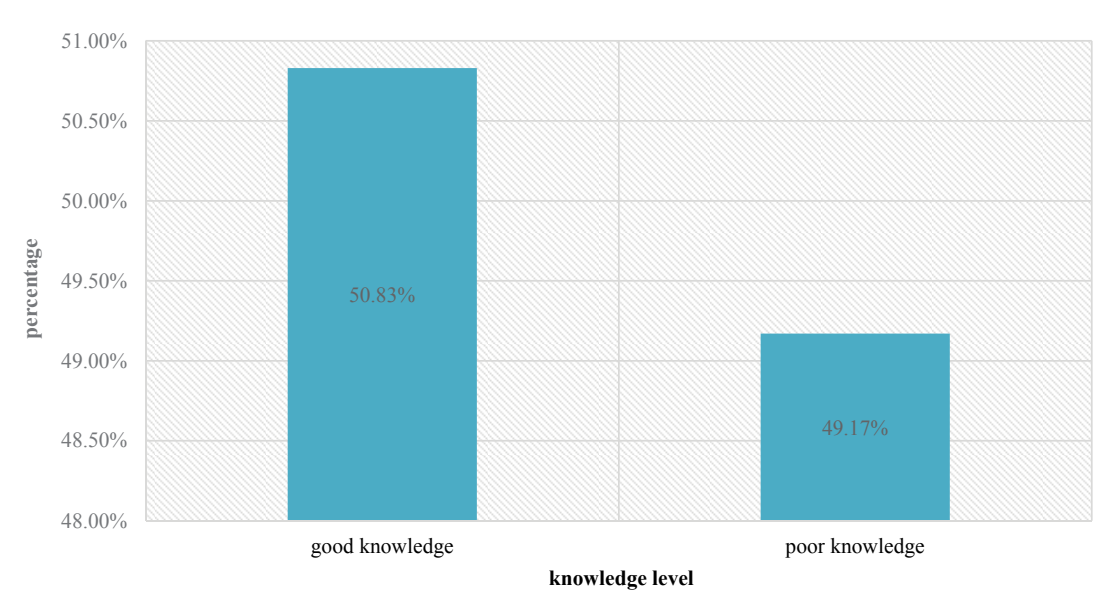

Figure 1: Kilture Preparatory School student's level of knowledge about STIs, at Arsi Negelle west Arsi zone, 2016.

Variable

Do you think patients with STIs are easily identified in the community?

Do you think sexually transmitted infections are not dangerous because they can be cured?

Do you think people who are infected with STI must get treatment?

Do you think young people should get information/ knowledge about STIs?

Do you think getting HIV and other STIs are more frustrating than other consequences when having unprotected sexual intercourse?

Do you think a person who does not want to become infected with STI should use condom?

Do you believe isolating an individual who had STI can help prevent spread of the disease?

Do you think there are both cured and non-cured STI?

Do you think STIs can transmit by other means than?

Mean (SD) Attitude score 7.5 (1.2), Min. scores 3- max. score 9

\begin{tabular}{|c|c|c|c|}
\hline & \multicolumn{3}{|c|}{$\begin{array}{c}\text { Response indicating desirable } \\
\text { attitude (\%)according to sex } \\
\text { Sex }\end{array}$} \\
\hline $\begin{array}{c}\text { Appropriate } \\
\text { response }\end{array}$ & $\begin{array}{c}\text { Male } \\
\text { (181) }\end{array}$ & $\begin{array}{c}\text { Female } \\
\text { (122) }\end{array}$ & $\begin{array}{c}\text { Total } \\
\mathbf{3 0 3}\end{array}$ \\
\hline No & 137 & 96 & $76.9 \%$ \\
\hline No & 125 & 64 & $62.4 \%$ \\
\hline Yes & 164 & 118 & $93.1 \%$ \\
\hline Yes & 178 & 120 & $98.3 \%$ \\
\hline Yes & 171 & 108 & $92.1 \%$ \\
\hline No & 172 & 116 & $95.1 \%$ \\
\hline Yes & 137 & 93 & $76.9 \%$ \\
\hline Yes & 1421 & 103 & 80.9 \\
\hline & & & \\
\hline
\end{tabular}

Table 3: Attitudes of respondents towards STI in terms of their sex in Arsi Negelle town, west Arsi zone, Oromia, Ethiopia, 2016. 
Citation: Megersa ND, Ahmed SM, Gutema BT, Teshome GS, Melketsedik ZA, et al. (2017) Knowledge, Attitude and Preventive Practices towards Sexually Transmitted Infection among Preparatory School Students of Arsi Negelle Town. J AIDS Clin Res 8: 748. doi: 10.4172/21556113.1000748

Page 4 of 6

them didn't utilize condom. From those who had utilized condom 36 (11.9\%) used always, 26 (8.6\%) usually and $26(8.6 \%)$ sometimes.

With respect to taking measure for individual who is vulnerable to STI 156 (51.5\%) of respondents mentioned advising to abstain the individual as primarily action, 7 (2.3\%) wrongly advice individual as to wash his/her genitalia prior to sex (Figure 2).

From total of 117 students who had history of sexual intercourse only $38.6 \%$ of respondents had good preventive practice despite of the fact that the rest $61.4 \%$ had poor preventive practice towards STIs (Figure 3).

\section{Factors associated with knowledge of students towards STIs}

In bivariate logistic regression, sex, living with whom status, mothers and fathers of student's educational level was identified to have association with knowledge of students and p-value less than 0.2 was considered to run multivariate logistic regression and thus, sex of respondent and student's fathers' level of education were identified to have significant association with knowledge of respondents. Hence, male students were 1.80 times more likely to have good knowledge about STIs than female students (AOR, (95\% CI), $1.80(1.096,2.967))$. Likewise, respondents whose father had college and more educational level were 3.71 times more likely to have good knowledge about STIs than those whose father had no formal education (AOR, (95\% CI) $3.71(1.539,8.950))$ (Table 4).

\section{Factors associated with preventive practices of students}

In bivariate logistic regression respondent's father's and mother's

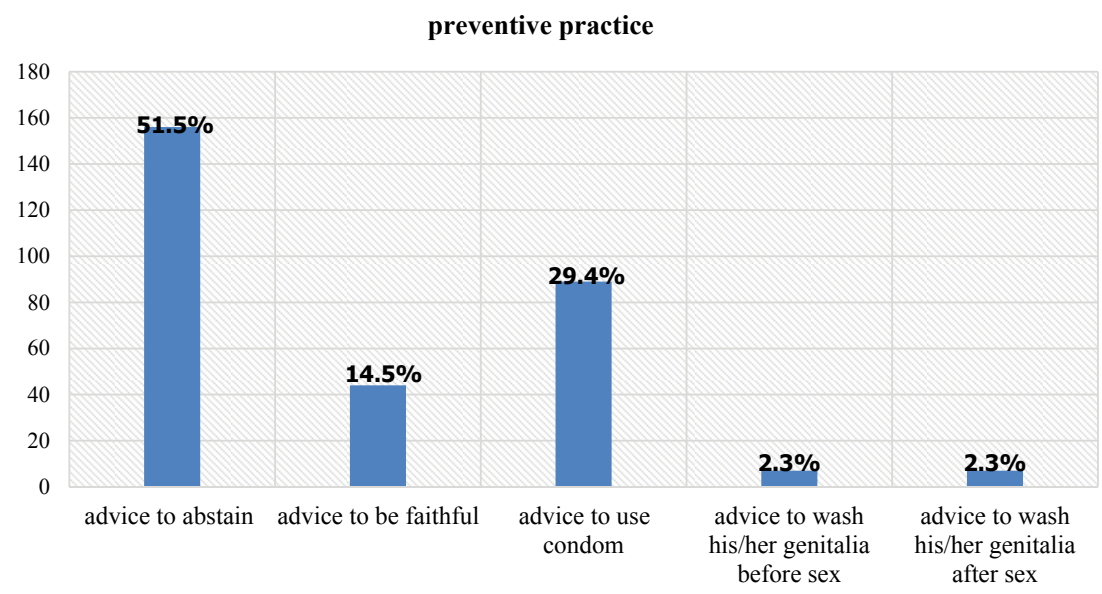

Figure 2: Kilture preparatory School Student's preventive practice for individual who are vulnerable, for contracting STIs in Arsi Negelle town, west Arsi zone, 2016.

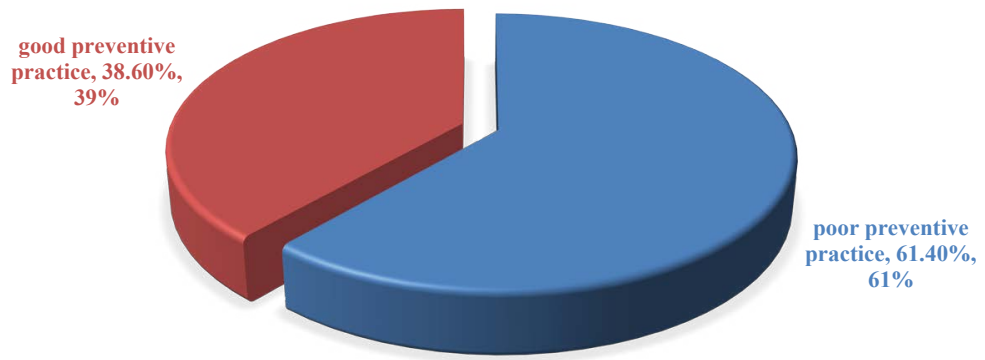

Figure 3: Kilture Preparatory School student's levels of preventive practices towards STIs at Arsi Negelle town west Arsi zone, 2016.

\begin{tabular}{|c|c|c|c|c|c|c|c|}
\hline \multirow[t]{2}{*}{ Variable } & \multirow[t]{2}{*}{ Category } & \multicolumn{2}{|c|}{ Knowledge of students } & \multirow[t]{2}{*}{ COR $(95 \% \mathrm{Cl})$} & \multirow[t]{2}{*}{$P$-value } & \multirow[t]{2}{*}{ AOR $(95 \% \mathrm{Cl})$} & \multirow[t]{2}{*}{$P$-value } \\
\hline & & $\begin{array}{l}\text { Poor } \\
\text { N (\%) }\end{array}$ & $\begin{array}{l}\text { Good } \\
\text { N (\%) }\end{array}$ & & & & \\
\hline \multirow{4}{*}{$\begin{array}{l}\text { Fathers level of } \\
\text { education }\end{array}$} & No formal education & $23(15.4 \%)$ & $11(7.1 \%)$ & 1 & & 1 & \\
\hline & Primary & $46(30.9 \%)$ & $47(30.5 \%)$ & $2.14(0.936,4.877$ & 0.072 & $2.13(0.916,4.969)$ & 0.079 \\
\hline & Secondary & $45(45 \%)$ & $47(30.5 \%)$ & $2.18(0.955,4.991)$ & 0.064 & $2.31(0.991,5.398)$ & 0.053 \\
\hline & College and above & $35(23.5 \%)$ & $49(31.8 \%)$ & $2.93(1.265,6.776)$ & 0.012 & *3.71 $(1.539,8.950)$ & 0.003 \\
\hline \multirow{3}{*}{ Sex } & Male & $82(55 \%)$ & $99(64.3 \%)$ & $1.47(0.927,2.333)$ & 0.101 & *1.80 (1.096, 2.967) & 0.02 \\
\hline & Female & $67(45 \%)$ & $55(35.7 \%)$ & 1 & & 1 & \\
\hline & Total & 149 & $154(100 \%)$ & & & & \\
\hline
\end{tabular}

*statistically significant association at $p$-value of $<0.05$

Table 4: Bivariate and multivariable logistic regression analysis result indicating factors associated with knowledge about STI among Arsi Negelle Kilture Preparatory School students, West Arsi z one, 2016. 
Citation: Megersa ND, Ahmed SM, Gutema BT, Teshome GS, Melketsedik ZA, et al. (2017) Knowledge, Attitude and Preventive Practices towards Sexually Transmitted Infection among Preparatory School Students of Arsi Negelle Town. J AIDS Clin Res 8: 748. doi: 10.4172/21556113.1000748

Page 5 of 6

\begin{tabular}{|c|c|c|c|c|c|c|c|}
\hline \multirow[t]{2}{*}{ Variable } & \multirow[t]{2}{*}{ Category } & \multicolumn{2}{|c|}{ Preventive practice } & \multirow[t]{2}{*}{ COR $(95 \% \mathrm{Cl})$} & \multirow[t]{2}{*}{$p$-value } & \multirow[t]{2}{*}{ AOR $(95 \% \mathrm{Cl})$} & \multirow[t]{2}{*}{$p$-value } \\
\hline & & Poor & Good & & & & \\
\hline \multirow{5}{*}{$\begin{array}{l}\text { Fathers level of } \\
\text { education }\end{array}$} & No formal education & $10(18.5 \%)$ & $2(5.9 \%)$ & $0.257(0.042,1.573)$ & 0.142 & $0.257(0.042,1.57)$ & 0.142 \\
\hline & Primary & $10(18.5 \%)$ & $14(41.2 \%)$ & $1.800(0.501,6.463)$ & 0.367 & $1.8(0.501,6.463)$ & 0.367 \\
\hline & Secondary & $25(46.3 \%)$ & $11(32.4 \%)$ & $0.566(0.168,1.908)$ & 0.358 & $0.566(0.168,1.908)$ & 0.358 \\
\hline & College and above & $9(16.7 \%)$ & $7(20.6 \%)$ & 1 & & 1 & \\
\hline & Total & $54(100 \%)$ & $34(100 \%)$ & & & & \\
\hline \multirow{5}{*}{$\begin{array}{l}\text { Mothers level of } \\
\text { education }\end{array}$} & No formal education* & $18(33.3 \%)$ & $5(14.7 \%)$ & $0.202(0.053,0.776)$ & 0.020 & $0.212(0.050,0.895)$ & 0.035 \\
\hline & Primary & $14(25.9 \%)$ & $10(29.4 \%)$ & $0.519(0.153,1.759)$ & 0.293 & $0.485(0.133,1.774)$ & 0.274 \\
\hline & Secondary & $14(25.9 \%)$ & $8(23.5 \%)$ & $00.416(00.118,10.463)$ & 0.171 & $0.413(0.109,1.554)$ & 0.193 \\
\hline & College and above & $8(14.8 \%)$ & $11(32.4 \%)$ & 1 & & 1 & \\
\hline & Total & $54(100 \%)$ & $34(100 \%)$ & & & & \\
\hline
\end{tabular}

*Statistically significant association at p-value of $<0.05$

Table 5: Bivariate and multivariable logistic regression analysis indicating factors associated with preventive practice of students towards STI among Arsi Negelle Kilture Preparatory School students, West Arsi zone, 2016.

level of education were declared to be candidate for multi variable logistic regression assuming p-value less than 0.2. In multi variable logistic regression mother's level of education were recognized to have significant association with respondent's preventive practices towards STIs. As a result, respondents, whose mothers had no formal education, were $78.8 \%$ less likely to have good preventive practice when compared with respondents whose mother had college and more educational level (AOR, 95\% CI $0.212(0.050,0.895))$ (Table 5).

\section{Discussion}

In this study 298 (98.3\%) of respondents had heard about STIs from different sources which was recognized to be almost similar with the finding of a study at shone town which was 295 (97.4\%) and it was relatively higher than a study held on Turkish Cypriot high school adolescents which revealed that $91.25 \%$ of students had heard about STIs from different sources the discrepancy in hearing about STIs may occurs due to increasing coverage of technology and information from time to time $[15,16]$.

With respect to knowledge of respondents about sign and symptoms of STIs the finding of this study revealed that $72.4 \%$ of respondent were aware of the sign and symptoms of STIs which is higher when compared with a study at Addis Ababa which was $17.9 \%$ and a study at Gonder which was $45.5 \%$ but the finding of this study was lower than a study at shone preparatory school which was $91.75 \%$. The difference in knowledge of students about sign and symptoms of STI may be attributable to time gabs between the studies and expansion of awareness creating programs and increased coverage of technologies $[15,17,18]$

Considering the knowledge of students about the different types of STIs in the current study $262(86.5 \%)$ had mentioned HIV as STIs while only $7(2.3 \%)$ of respondents know that HB is STIs which was considerably lower than the finding of a study done at Nepal which showed $96.6 \%$ boys and $86.6 \%$ girls had mentioned HIV/AIDS and $56.66 \%$ Hepatitis-B as they are grouped under STIs the difference in the two-study population may arises from difference in levels of civilization, growth and expanded coverage in technology and wide spread media coverage [19].

In this study $99.7 \%$ of respondents stated that they can prevent themselves from contracting STIs which was in line with the finding of a study at Dares Salaam, Tanzania in which $96 \%$ of students said they were able to protect themselves from contracting STIs the difference may be attributable to the time difference between these two studies [20].
In this study 259 (85.8\%) of students mentioned consistent use of condom as a primary method of prevention which is a bit lower than the finding of a study at Wolayita Sodo university which was $96.2 \%$. the variation may resulted from difference in respondent's level of education and habits of discussion about STIs [21].

With respect to misconception about modes of transmission of STIs 25(8\%) of respondents perceive that mosquito bite can transmit STIs when compared with the finding of study at Debrebrehan which showed $33 \%$ of participants perceived that STIs can transmit through mosquito bite thus, the difference might have resulted from dissimilarity in perceptions that is held in the two study settings in which the participants interact with [22].

In this study $45.5 \%$ of respondents had negative attitude which is significantly larger when compared with findings of study conduct at shone preparatory school which was $15.18 \%$ and study at Gonder which was $34 \%$, this considerable variance in attitude may be attributable to the level of knowledge of students and sociodemographic [15,17].

In this study 117 (38.6\%) respondents reported as they had history of sexual intercourse from this 29 did not utilize condom while the remaining used condom and from users only $36(11.9 \%)$ of respondents exploit it properly and consistently when compared with study conducted at shone about $41.25 \%$ of the respondents have history of sexual intercourse, from those who had sex, 89 (71.20\%) had used condom and $36(28.80 \%)$ did not use it. Among condom users 31 (34.83\%) utilize always, which is a bit higher than in utilizing condom the discrepancy might have resulted from difference in knowledge and attitude about STI. Knowledge of respondents had significant association with respondent's father's level of education and sex of respondents. This finding is in line with the finding of a study at Debrebrehan [22].

\section{Limitation of the Study}

- Self-reported information is subjected to reporting errors, missed values and biases.

- Since the study touches sensitive issues the possibility of underestimation and under reporting cannot be excluded.

- Cross- sectional study design was employed for this study. This type of study design shows the exposure and outcome at the same point in time, so that we cannot formulate cause and effect relationship. 
Citation: Megersa ND, Ahmed SM, Gutema BT, Teshome GS, Melketsedik ZA, et al. (2017) Knowledge, Attitude and Preventive Practices towards Sexually Transmitted Infection among Preparatory School Students of Arsi Negelle Town. J AIDS Clin Res 8: 748. doi: 10.4172/21556113.1000748

Page 6 of 6

\section{Conclusion and Recommendation}

Most of respondents had heard about STIs however, only nearly half of them have good knowledge about STIs. Male respondents had poor preventive practice when compared with female. More than half of study participants had positive attitude however still there was miss conception that an individual with STIs can be easily identified in the community and isolating this group of individual from the other community member, can be helpful in controlling the spread of disease. School administration should design strategies on how to build on the existing level of knowledge, attitude and preventive practice. Gender clubs and anti-HIV clubs. Further research may need to identify factors that are associated with gender inequalities in terms of knowledge, attitude and preventive practice towards STIs in the study area.

\section{Ethics Statement}

The study protocol was approved by Addis Ababa University College of health sciences institutional review board AAU MF 008 version 2 with protocol number $104 /$ Nulfe on $21 / 01 / 2016$

\section{Acknowledgement}

I would like to express my profound gratitude and deep appreciation to Addis Ababa University College of health science school of allied health sciences department of nursing and midwifery who provides me this opportunity to carry out this research.

I am particularly very grateful for the special assistance of Mr. Girum Sebsebie for the guidance and direction which he offered me throughout the process.

\section{Key message}

The existing facts that initiates me to carry out the current study was observed gaps or lack of knowledge of students regarding the common STIs including HIV which was confirmed by individuals who are a friend of me working in the study area school. The finding of this study identified that students have poor knowledge regarding the common STIs with exception of HIV in which they have relatively good knowledge. So limitation of knowledge make students practice sexual intercourse in unsafe and non-protective manner which in turn put them on an increased risk of contracting and transmitting STIs.

\section{References}

1. Casey CG, Rutledge TF, Boyd MF, Starr TM (2010) Morbidity and mortality weekly report sexually transmitted diseases treatment guidelines, 2010 department of health and human services. Sex Transm Dis 59: 1-110.

2. Lazarus JV, Sihvonen-Riemenschneider H, Laukamm-Josten U, Wong $F$ Liljestrand J (2010) Systematic review of interventions to prevent the spread of sexually transmitted infections, including HIV, among young people in Europe. Croat Med J 51: 74-84.

3. Ethiopia (2003) H prevention and control office ministry of health in collaboration with U president's plan for a relief (PEPFAR) through department of health and human service $C$ office in. National Guidelines for the Management of STIs Using the Syndromic Approach 8-59.

4. Matkins PP (2013) Sexually transmitted infections in adolescents. N C Med J 74: 48-52.
5. Goldmeier AM (2015) Sexually Transmitted Infections (STIs) The importance of a renewed commitment to STI prevention and control in achieving global sexual and reproductive health. WHO Libr Cat Data Sex, pp: 1-8.

6. Cossio MLT, Giessen LF, Araya G, Pérez-Cotapos MLS, Vergara RL, et al. (2012) Uma ética para quantos. XXXIII: 81-87.

7. World Health Organization (2014) Baseline report on global sexually transmitted infection surveillance 2013. WHO 54.

8. UNAIDS (2013) Global report: UNAIDS report on the global AIDS epidemic UNAIDS 272.

9. WHO (2007) Global Strategy for the Prevention and Control of Sexually Transmitted Infections: 2006-2015, breaking chain of transmission. Sexual and reproductive health, Geneva, Switzerland 61.

10. CDC (2007) Sexually transmitted infections in developing countries: Current concepts and strategies on improving STI prevention, treatment, and control. CDC, Geneva, Switzerland, pp: 1-60.

11. Kassie A, Shume A, Kloos H (2006) Sexually transmitted infectious. The Epidemiology and Ecology of Health and Disease in Ethiopia

12. WHO, UNAIDS. Global AIDS response progress reporting 2015. WHO UNAIDS, pp: 12-18.

13. Central Statistical Agency, ICF International (2012) Ethiopia Demographic and Health Survey 2011. Central Statistical Agency and ICF International, Addis Ababa, Ethiopia and Calverton, Maryland, USA.

14. Central Statistical Agency of Ethiopia National Census (2007) Population and housing census of Ethiopia. Results for Oromia region.

15. Kejela G, Bikila S (2015) Assessment of knowledge, attitude and preventive practices towards sexually transmitted infections among preparatory schoo students in Shone Town. Health Med Informatics 6: 1-6.

16. Kaptanoglu AF, Suer K, Diktas H, Hincal E (2013) Knowledge, attitudes and behaviour towards sexually transmitted diseases in Turkish Cypriot adolescents. Cent Eur J Public Health 21: 54-58.

17. Shiferaw Y, Alemu A, Girma A, Getahun A, Kassa A, et al. (2011) Assessment of knowledge, attitude and risk behaviors towards HIVIAIDS and other sexual transmitted infection among preparatory students of Gondar town, north west Ethiopia. BMC Res Notes 4: 505.

18. Cherie A, Berhane $Y$ (2012) AIDS and clinical knowledge of sexually transmitted infections and barriers to seeking health services among high school adolescents in Addis Ababa, Ethiopia. J AIDS Clin Res 3.

19. Gupta S, Khanal TR, Gupta N, Thakur A, Khatri R, et al. (2011) Knowledge behavior and attitude towards sexually transmitted infections and acquired immunodeficiency syndrome of adolescent students. J Nepal Health Res Counc 9: 44-47.

20. Mwambete KD, Mtaturu Z (2006) Knowledge of sexually transmitted diseases among secondary school students in Dares Salaam, Tanzania. Afr Health Sc 6: $165-169$.

21. Yohannes B, Terefe Gelibo MT (2013) Prevalence and associated factors of sexually transmitted infections among students of Wolaita Sodo University, Southern Ethiopia. Int J Sci Technol Res 2: 1-9.

22. Adera AG (2015) Assessment of knowledge, attitude and practice of students towards sexually transmitted infection in Haile Mariam Mamo Preparatory School Debre Birhan, Ethiopia, 2013. Sci J Public Health 3: 563 